Article

\title{
Climate Change and Public Policies in the Brazilian Amazon State of Mato Grosso: Perceptions and Challenges
}

\author{
Neli Aparecida de Mello-Théry ${ }^{1} * \mathbb{D}^{\mathbb{D}}$, Eduardo de Lima Caldas ${ }^{1}$, Beatriz M. Funatsu ${ }^{2}$ (D), \\ Damien Arvor ${ }^{3}$ a and Vincent Dubreuil ${ }^{3}$ (D) \\ 1 Escola de Artes, Ciências e Humanidades (EACH), Universidade de São Paulo, \\ São Paulo 03828-000, Brazil; eduardocaldas@usp.br \\ 2 CNRS, Université de Nantes, LETG UMR 6554, 44312 Nantes, France; beatriz.funatsu@univ-nantes.fr \\ 3 CNRS, Université Rennes 2, LETG UMR 6554, 35000 Rennes, France; \\ damien.arvor@univ-rennes2.fr (D.A.); vincent.dubreuil@univ-rennes2.fr (V.D.) \\ * Correspondence: namello@usp.br
}

Received: 19 May 2020; Accepted: 16 June 2020; Published: 23 June 2020

check for updates

\begin{abstract}
This study examines how key stakeholders in agriculture in a number of municipalities in the Brazilian Amazon state of Mato Grosso are incorporating and adapting to public policies on climate change. Fieldwork and semi-structured interviews conducted in 2014 and 2018 with key stakeholders in the region were analyzed to assess the effectiveness of public policies incorporating climate change factors. Data obtained from documents from national institutions complemented these interviews. The results show that although local government claims that its mission is economic, social and sustainable development, and although public institutions and stakeholders repeat internationally recognized protocols and agreements in their communications, in actual fact, these are not reflected by any change in institutional behavior.
\end{abstract}

Keywords: climate change perceptions; adaptation policies; public policies; agriculture; municipalities in Mato Grosso

\section{Introduction}

The issue of climate change is controversial. Although widely accepted as a reality within the bio-geosphere scientific community [1], outside this field there is a wide range of alternative views (those who deny its existence completely, those who remain unconvinced, uninterested, unengaged, etc. [2]). Uncertainty surrounding the extent of such changes at local and regional levels partly explains the reluctance to accept the existence of climate change, as well as the reluctance to accept the urgency of the need to mitigate and adapt to it [3]. This is because any such acceptance would require a complete transformation of both personal and organizational/institutional behavior [4]. In addition, modifications affect stakeholder perceptions, ideas, institutions and interests [5]. Governmental commitments made at the Conference of the Parties ( $\mathrm{CoP}$ ) meetings have seen steps both forwards and backwards in terms of mitigation and adaptation to climate change [6-8]. The issue has now become a challenge to society as a whole since the 4 th report (A4R) by the Intergovernmental Panel on Climate Change (IPCC), which acknowledged the need to adapt to climate change and changed the focus from mitigation only [9]. This could be interpreted as a step backwards because sharing responsibility with the population could potentially be seen as blurring governmental obligations [10]. However, it could also be seen as an opportunity to consolidate both governmental commitments and individual actions [11]. 
Our considerations and approach to climate change are founded on two concepts: that of perception and that of adaptation. The perception of climate change is a new approach in climatology, and it aims to analyze and understand the climate through human perception. Perception of climate change can be defined as the awareness or belief in its existence [12]; it values humankind's sensitivity and subjectivity as a means of understanding its surroundings. Such perceptions can be shaped by several factors (age, gender, political views, scientific exposure and/or, life experience to climatic events, etc.) that might influence how these perceptions lead to change [12-21]. In turn, adaptation is a system of interactions between individuals and the constructed environment that depends on strategic and tactical action [22-26]. While perceptions depend on individuals' ability to take in their environment, adaptation measures are subject to specific economic situations [25-29].

In this study, we examine whether and how these two concepts laid out above-namely, perception and adaptation-are being recognized by agricultural stakeholders and integrated in local public policies. Our study applies to municipalities in the state of Mato Grosso, Brazil, a region affected by aggressive deforestation from the 1970s onwards in order to expand intensive agriculture, followed by intensive land use and mixed economic development (see, e.g., [30,31] and references therein). As such, the region provides a rich ground for geography, sustainable development, political sciences and climate studies, with several aspects of socio-economic development, mitigation strategies for land use and environmental conservation being the subjects of numerous studies (e.g., [31-70]).

In the past few decades the concept of "policy mix", in which multiple goals and instruments are taken into account in order to reach policy goals, has been acknowledged as needed in order to address both climate change and land use concerns ([59] and references therein). In addition to the diversity of instruments, there is the issue of the multiple governance levels, which adds an additional level of complexity to the policy decision process. In Brazil, environmental governance is typically characterized by a top-down approach, in which most decisions are taken at federal level [59,71-75]. Caldas and Moreira [75] showed that, in the case of Mato Grosso, state national policies are more smoothly absorbed and implemented whenever there is an alliance between the government at state and federal levels. The Fundação Estadual do Meio Ambiente (FEMA; State Foundation of the Environment) in Mato Grosso implemented programs in the late 1990s to comply with federal legislation on land clearing, which by 2001 had a significant effect on deforestation even if their enforcement was varied at municipal levels [50,51].

Since the 2000s, the agricultural sector has evolved rapidly in order to better combine socioeconomic development with environmental governance [31,59]. This represents a tremendous challenge in the context of frontier expansion, and various positive achievements should be emphasized: (1) a drastic decrease in deforestation rates since 2004, due to the efficient combination of command-and-control policies associated with market-oriented agreements [31,55,60,76]; (2) the widespread adoption of no-till planting, and more generally, the adoption of Low Carbon Agriculture (ABC) to promote new environmentally friendly agricultural practices, such as crop-livestock integrated systems (ILP) [54,70]; (3) the emergence of the Roundtable for Responsible Soy (RTRS), which certifies soy as a responsible crop for producers adopting good agricultural practices and respecting labor conditions, community relations and environmental laws [77]; (4) the MT Legal project [33], derived from the Lucas Legal project $[58,68,78]$, which highlights the feasibility of transferring a municipal environmental policy onto a state scale, thus reflecting a very interesting institutional dynamism; and (5) the implementation of a recent jurisdictional approach named "Produce, Conserve, Include" (PCI) with the goal of improving the "policy mix" strategy by bringing multi-stakeholders (government, civil society, producers and companies) together in order to "ensure that local laws, regional efforts, and corporate policies work in concert to catalyze reduced deforestation at scale." (https://wedocs.unep.org/handle/20.500.11822/28871).

Although these efforts illustrate the desire of the agricultural sector to promote sustainable development, it also questions its underlying motivations since (1) the recent increase in deforestation rates suggest that economic factors still prevail over environmental considerations to drive the agricultural frontier, and (2) climate change is still rarely mentioned as a reason to improve the 
agricultural development model. This indicates that the bridge between scientists, stakeholders and policy makers remains tenuous.

According to Shreraga et al. [79], the process in which scientific reports are integrated in the decision-making process is by policy-focused assessments, in which "timely and useful information about the possible consequences of climate change, people's perceptions of whether the consequences are positive or negative, available adaptation options, and the benefits of slowing the rate of climate change" is made available to policymakers. However, even with the availability of IPCC Assessment Reports, the decision-making process of environmental public policies in Brazil is often based on either personal experience or expert (not necessarily scientific) advice and motivated by political or economic interests [80]. In Mato Grosso, a typological analysis of interactions between policy instruments showed that science support did not appear in the connectivity network of policy making [59], even though the dominant agricultural activity is highly dependent on weather and climate conditions. We, thus, seek to evaluate whether and how agricultural stakeholders were making provisions for the evolution of the agricultural sector in an area where evidence of climate change has been reported in various scientific studies $[36,39,43,47,52]$.

In addition to the introduction and conclusion, this article is composed of three further sections. Section 2 introduces the conceptual framework for the perception of and adaptation to climate change. Section 3 sets out the working methodology and underlying issues of the study, and it presents the key stakeholders identified for this study. Section 4 presents and analyzes the stakeholders' perception of consequences for agriculture, as well as their perception of public policies.

\section{Perceptions of Climate Change and Adaptation Policies}

Mendonça [16] suggests that the framework for climate change studies is founded on complexity theory and reinforces the need to adopt more holistic approaches. For him, the Climate Network in Brazil, which works together with several other countries and exploits the inter-disciplinary interfaces between the physical and natural sciences and applied humanities, offers a new dimension for knowledge production and is an important element in the study of adaptation and adaptation policies regarding climate change.

It is this holistic approach that underlies the concept of perception of climate change. It was J. Pérard [81] who first introduced the concept of perception in considering that, in order to combat climate risks and improve climate resource management, there were two complementary scientific approaches that, while essential, were also quite distinct. According to Pérard [81], climatological analysis of only physical models was inadequate, as it did not consider human factors. Therefore, climate data, complex analysis of such data, knowledge production and information generation were not sufficient if efficient transmission to stakeholders (definition from the Cambridge dictionary: "a person such as an employee, customer, or citizen who is involved with an organization, society, etc. and therefore has responsibilities towards it and an interest in its success")-from the general population to lawmakers-did not properly convey these scientific findings [12,17]. This prior knowledge could also then be confronted with perceptions of local stakeholders. Thus, for the purposes of this study, perception is understood as a subjective phenomenon and as one that is often passed on between very different groups of stakeholders.

This concept of perception goes hand-in-hand with that of adaptation, which, seen from a biophysical, socio-economic and technical perspective, has been constructed by agriculturalists through an understanding that the physical environment reacts to new cultures and techniques [82,83].

For Obermaier and Rosa [84], the issue of adaptation in developing countries encompasses a more holistic view within the social sciences and humanities, associating it with developmental vulnerabilities, and it goes beyond the bio-physical impacts of global environmental problems. They agree with the IPCC's claim about the importance of identifying the causes and effects of such vulnerabilities, and they attempt to set pathways that will increase the capacity for adaptation and reduce exposure 
and sensitivity to socio-environmental systems. They also agree with Mendonça [16], that adaptation and vulnerability are part of the systemic analysis of socio-environmental resiliency.

To interpret stakeholders' perceptions, before even looking at regional or local climatic characteristics, it is first essential to highlight the importance that Dubreuil et al. [47] gives to the concepts of "variation" and "variability" in the understanding of climate change. Here, variation means a long-lasting and progressive modification of the climate, which decade after decade may become colder or warmer. Humankind does not always perceive this progressive evolution. The concept of variability can be defined as a climatic parameter that hovers around a reference value considered as "normal", and is one that is usually based on a 30 year period. This means that there may be hotter or drier years that society will need to react to, and when reactive practices are no longer enough, they need to be replaced with more permanent practices, and are thus seen as adaptation.

The spatial-temporal variability of climate is the result of a combination of several interconnected factors at a multitude of levels. The effects of global and continental oceanic and atmospheric conditions can be modulated locally according to land occupation [39,85-87], which also affects the physical characteristics of the lower layers of the atmosphere (temperature, wind, rainfall, aerosol composition and concentration) that can have a greater or lesser impact, and that can also be perceived at a local level.

As regards to the implementation of climate policies, authors like Drews and Van den Bergh [88] believe that effective implementation of climate change policies must be founded on public support. They go on to classify the factors that influence support for climate change policies into three general categories:

1. Socio-psychological factors and the perception of climate change, which include the positive influence of people identified with left-wing policies, egalitarian world views, environmental values and self-transcendence, awareness of climate change, risk perception and emotions such as interest and hope;

2. The perception of climate policy design, which includes pressuring measures, the positive effect of legislation, the effectiveness of policies, the costs of policies and the recycling of potential revenue policies;

3. Contextual factors, such as the positive influence of social trust, norms and participation, broader economic, political and geographical aspects, and the different effects of specific events and methods of communication.

Drews and Van den Bergh [88] also introduce the variable of "public opinion" to the debate on climate change. In this context, it is fundamental to understand the public's perception of climate change as a socio-political event, in order to establish a communication policy supported by public opinion and put the theme of "climate change" firmly on the government's agenda.

The issue of climate change and its risks has also been analyzed by Anderegg and Goldsmith [89]. They measured public interest (using online searches as a proxy) on climate and climate change during and after a climatic event and found out that there is a rapid decay from $80 \%$ during the first three days to about only $10 \%$ searches after three weeks. They suggest that climate scientists need to re-examine how to involve the public more effectively. Indeed, communication of risk information among the local population, technical experts and policy makers is not straightforward $[17,90]$ and needs to appeal to the moral or social responsibility in order to yield sustainable action [12].

\section{Method}

This interdisciplinary approach embraces geographical, multidimensional and multilevel elements. This multilevel concatenation is founded principally on the idea that all environmental problems transcend borders, affect everything and everyone on the planet, and affect the vital links between decisions taken at various levels (from local to international) as the commitments and actions of and by the countries in international forums tend to influence more local policies [62,91]. In the absence of any 
articulated national policy, analysis of public actions allows one to examine public actions of municipal players and the (in)consistencies between perception, speech and the tools used for public action.

Therefore, from a methodological perspective, the following steps were

(a) definition of the region according to location, with area of agricultural expansion;

(b) based on item (a), territorial characterization and use of data on temperature and rainfall and other official information from local institutions as a basis for analysis of public perception and policies;

(c) description of the production areas and agricultural production development infrastructure; and

(d) identification of key stakeholders.

For steps (a)-(c), four municipalities in the state of Mato Grosso (MT) were chosen as study areas: Alta Floresta, Lucas do Rio Verde, Sorriso and Sinop (Figure 1). Alta Floresta is characterized by small to medium-sized farm and cattle ranches [47,70]. Lucas do Rio Verde and Sorriso are strongly associated with agro-business, being, respectively, the first municipality for the business of agrotechnology and for soy production at national scale [33,34]. Sinop is the major urban pole in northern Mato Grosso supported by powerful agro-industrial firms and the rapid development of a service economy [33,40,42]. A more detailed description of the study sites in the context of sustainable development can be found, for example, in Droulers and Le Tourneau [45].
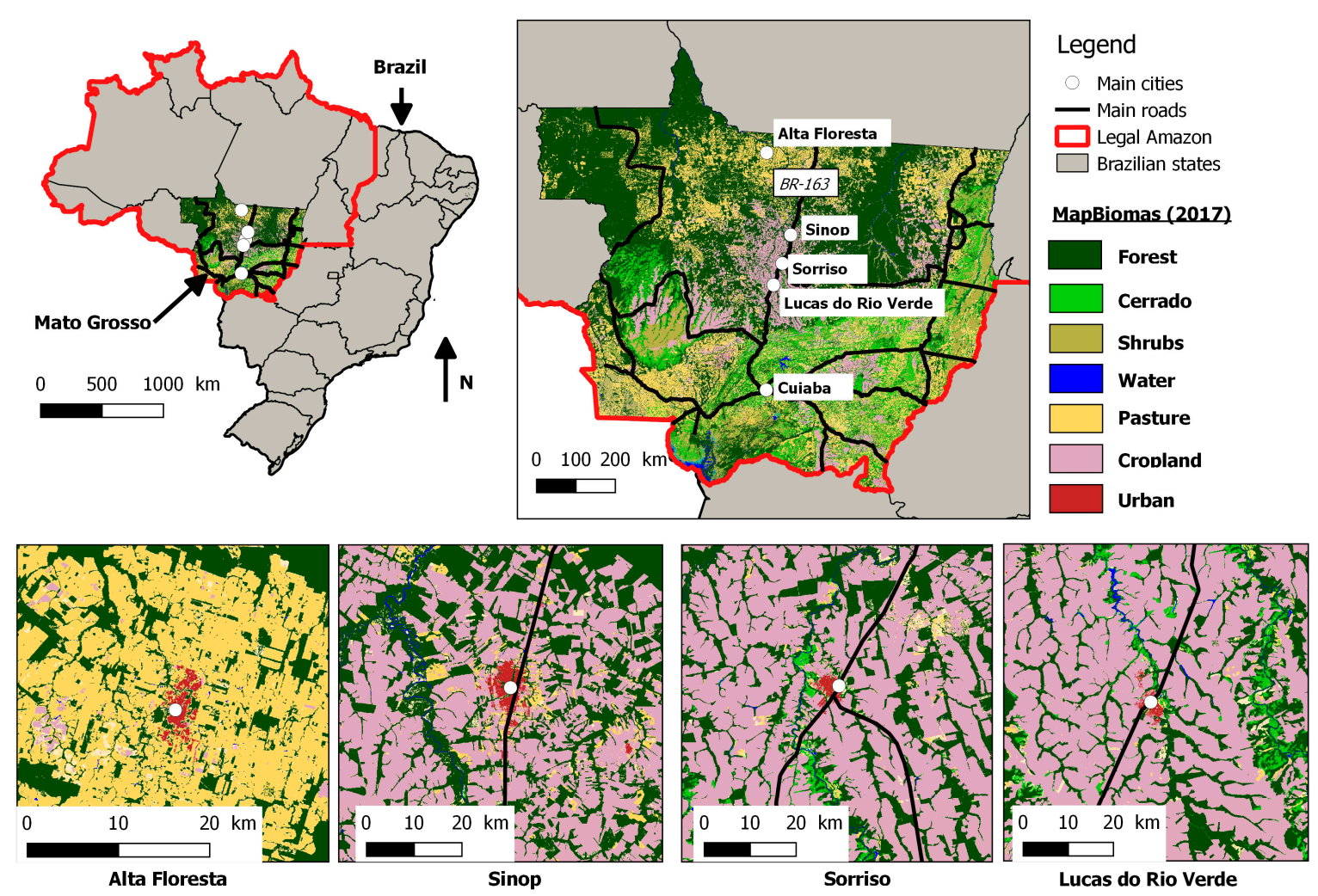

Figure 1. Locations of Alta Floresta, Sinop, Sorriso and Lucas do Rio Verde in the state of Mato Grosso, Brazil. Land cover classification for 2017 obtained from the Mapbiomas project (www.mapbiomas.org).

For step (d), the key stakeholders were identified to represent a large panel of agents of the agricultural sector: Federations and associations, trade unions, seed stores, municipal departments and other public organizations, governmental institutions, producers and local researchers, with diverse interests, some being focused on agricultural development while others are more committed to environmental preservation. The specific stakeholders are listed in Table 1. 
Table 1. List of interviewed key stakeholders.

\begin{tabular}{|c|c|c|c|c|c|c|}
\hline Stakeholders & $\begin{array}{c}\text { Type of } \\
\text { Organization }\end{array}$ & $\begin{array}{l}\text { Field of Activities/ } \\
\text { Mission Statement }\end{array}$ & $\begin{array}{l}\text { Number of } \\
\text { People } \\
\text { Interviewed }\end{array}$ & $\begin{array}{l}\text { Geographical } \\
\text { Scope }\end{array}$ & Locality & Date \\
\hline $\begin{array}{c}\text { ICV } \\
\text { (Instituto Centro de Vida) }\end{array}$ & NGO & $\begin{array}{l}\text { Implementation of local } \\
\text { sustainable development } \\
\text { projects }\end{array}$ & 1 & State & $\begin{array}{c}\text { Cuiabá/ } \\
\text { Alta Floresta }\end{array}$ & 20 Jan 2014 \\
\hline $\begin{array}{l}\text { Aprosoja (Associação dos } \\
\text { produtores de soja e } \\
\text { milho do Mato Grosso) }\end{array}$ & $\begin{array}{c}\text { Private } \\
\text { non-profit } \\
\text { association }\end{array}$ & $\begin{array}{l}\text { Association of soy and } \\
\text { maize producers }\end{array}$ & 1 & State & Cuiabá & 21 Jan 2014 \\
\hline $\begin{array}{c}\text { IMEA } \\
\text { (Instituto Matogrossense } \\
\text { de Economia } \\
\text { Agropecuaria) }\end{array}$ & $\begin{array}{l}\text { Private } \\
\text { non-profit } \\
\text { institute }\end{array}$ & $\begin{array}{l}\text { Improve economic } \\
\text { knowledge in order to } \\
\text { support sustainable } \\
\text { development of the } \\
\text { agribusiness sector }\end{array}$ & 1 & State & Cuiabá & 21 Jan 2014 \\
\hline $\begin{array}{c}\text { FETAGRI } \\
\text { (Federação dos } \\
\text { Trabalhadores na } \\
\text { Agricultura em Mato } \\
\text { Grosso) }\end{array}$ & $\begin{array}{l}\text { Private } \\
\text { non-profit } \\
\text { association }\end{array}$ & Labor Union & 1 & State & Cuiabá & 27 Jan 2014 \\
\hline $\begin{array}{l}\text { SEMA-LRV } \\
\text { (Secretary of } \\
\text { Environment) }\end{array}$ & Public & $\begin{array}{l}\text { Environmental } \\
\text { Management }\end{array}$ & 1 & $\begin{array}{c}\text { Local } \\
\text { (Municipal) }\end{array}$ & $\begin{array}{l}\text { Lucas do Rio } \\
\text { Verde }\end{array}$ & 28 Jan 2014 \\
\hline $\begin{array}{c}\text { FRV } \\
\text { (Fundação Rio Verde) }\end{array}$ & $\begin{array}{c}\text { Private } \\
\text { non-profit } \\
\text { foundation }\end{array}$ & $\begin{array}{l}\text { Technological support for } \\
\text { agribusiness }\end{array}$ & 1 & State & $\begin{array}{l}\text { Lucas do Rio } \\
\text { Verde }\end{array}$ & 29 Jan 2014 \\
\hline $\begin{array}{c}\text { EMBRAPA } \S \\
\text { (Empresa Brasileira de } \\
\text { Pesquisa Agropecuária) }\end{array}$ & $\begin{array}{l}\text { Public } \\
\text { Research } \\
\text { Institute }\end{array}$ & $\begin{array}{l}\text { Technological innovation } \\
\text { company for agriculture } \\
\text { and ranching }\end{array}$ & 1 & National & Sinop & 31 Jan 2014 \\
\hline $\begin{array}{l}\text { CONAB (Companhia } \\
\text { Nacional de } \\
\text { Abastecimento) }\end{array}$ & Public & $\begin{array}{l}\text { Strategical management of } \\
\text { food supply chain }\end{array}$ & 1 & National & Sinop & 31 Jan 2014 \\
\hline ICV & NGO & $\begin{array}{l}\text { Implementation of local } \\
\text { sustainable development } \\
\text { projects }\end{array}$ & 1 & State & Alta Floresta & 5-6 Jun 2014 \\
\hline $\begin{array}{c}\text { FEC (Fundação Ecológica } \\
\text { Cristalino) }\end{array}$ & NGO & $\begin{array}{l}\text { Biodiversity conservation, } \\
\text { green economy, } \\
\text { and environmental } \\
\text { education }\end{array}$ & 1 & Local & Alta Floresta & 5-6 Jun 2014 \\
\hline Farmers & Private & Cattle ranchers & 2 & Local & Alta Floresta & 5-6 Jun 2014 \\
\hline Farmers-SRS & Private & Soy farms & 24 & Local (Farm) & Sorriso & 2014 \\
\hline $\begin{array}{c}\text { CAT-SRS } \\
\text { (Clube dos Amigos da } \\
\text { Terra) }\end{array}$ & $\begin{array}{l}\text { Private } \\
\text { non-profit } \\
\text { association }\end{array}$ & $\begin{array}{c}\text { Support the } \\
\text { implementation of } \\
\text { sustainable development } \\
\text { projects in large-scale } \\
\text { agriculture }\end{array}$ & 1 & State & Sorriso & 2014 \\
\hline $\begin{array}{c}\text { SMADS-SNP } \\
\text { (Secretary of Environment } \\
\text { and Sustainable } \\
\text { Development) }\end{array}$ & Public & $\begin{array}{l}\text { Environmental } \\
\text { Management }\end{array}$ & 1 & $\begin{array}{c}\text { Local } \\
\text { (Municipal) }\end{array}$ & Sinop & $\begin{array}{c}29 \& 30 \text { May } \\
2018\end{array}$ \\
\hline $\begin{array}{l}\text { EMPAER (Empresa } \\
\text { Mato-grossense de } \\
\text { Pesquisa, Assistência e } \\
\text { Extensão Rural) }\end{array}$ & Public & $\begin{array}{l}\text { Technological support for } \\
\text { small-scale agriculture }\end{array}$ & 2 & State & Sinop & 29 May 2018 \\
\hline $\begin{array}{c}\text { SA-SNP } \\
\text { (Secretary of Agriculture) }\end{array}$ & Public & Agriculture Management & 1 & $\begin{array}{c}\text { Local } \\
\text { (Municipal) }\end{array}$ & Sinop & 01 Jun 2018 \\
\hline $\begin{array}{c}\text { ACRINORTE (Associação } \\
\text { dos Criadores do Norte } \\
\text { do MT) }\end{array}$ & Private & $\begin{array}{l}\text { Support for Ranchers in the } \\
\text { North of MT }\end{array}$ & 1 & State & Sinop & 01 Jun 2018 \\
\hline $\begin{array}{c}\text { SR-SNP } \\
\text { (Sindicato Rural de Sinop) }\end{array}$ & Private & Labor Union & 1 & $\begin{array}{c}\text { Local } \\
\text { (Municipal) }\end{array}$ & Sinop & 01 Jun 2018 \\
\hline
\end{tabular}

Notes: ${ }^{\S}$ EMBRAPA has a special statute as a state-owned, for profit enterprise, linked to the Brazilian Ministry of Agriculture, Livestock and Supply. 
Interviews with a semi-structured script were set up with the key agricultural stakeholders identified in (d) above and were conducted between 20 and 31 January 2014, 6 and 14 June, and 29 May and 1 June 2018 (Table 1). In terms of climate, 2013-2014 was a year with abundant rainfall in northern Mato Grosso, with reported crop losses due to humidity, whereas in 2017-2018 rainfall totals fell within the normal range in most of the region, though with sporadic very intense rainfall events recalled by laypeople during our field work. The interviews with stakeholders focused on the relation between the current perceptions of different stakeholders on climate change, the impact of climate change on agricultural activities, the vulnerability of current production systems and the relation between climate change and public action. Table 2 summarizes the questions from the semi-structured script organized into subtopics.

Table 2. Selection of questions from the semi-structured interview script.

\begin{tabular}{|c|c|}
\hline Subtopics & Questions \\
\hline $\begin{array}{l}\text { Seasonality, variation and } \\
\text { climate variability }\end{array}$ & $\begin{array}{l}\text { Have you noticed/sensed/perceived that the climate is colder, hotter, rainier, } \\
\text { drier? Have you noted climate "markers" in } \mathrm{C}^{\circ} \text {, rainfall }(\mathrm{mm}) \text {, at a given time } \\
\text { of year? }\end{array}$ \\
\hline $\begin{array}{l}\text { Consequences of variation } \\
\text { and climate variability }\end{array}$ & $\begin{array}{c}\text { Have you noticed/sensed/perceived the need to change the date for sowing, } \\
\text { i.e., delaying it or bringing it forward; a loss of agricultural products? } \\
\text { Any changes to the intensity and/or frequency of extreme weather events? } \\
\text { Any change to the start and end of the rainy season and its consequences on } \\
\text { sowing and crop productivity? }\end{array}$ \\
\hline $\begin{array}{l}\text { Vulnerabilities of local } \\
\text { production systems }\end{array}$ & $\begin{array}{c}\text { Have you noticed/sensed/perceived any changes to the price of and need for } \\
\text { fertilizers, quantity of water, adjustments for production systems and } \\
\text { techniques (tillage; increase/decrease of fertilizer or pesticide use, } \\
\text { energy consumption)? }\end{array}$ \\
\hline Policies and actions & $\begin{array}{l}\text { Are you aware of any existing public policies and actions (financial support, } \\
\text { debt write off schemes, etc.)? } \\
\text { Are there any hindrances to production (labor costs, infrastructure, legislation, } \\
\text { fiscal monitoring)? }\end{array}$ \\
\hline
\end{tabular}

Source: Questions adapted from DURAMAZ research projects $[45,57]$ and Sustentabilidade da produção agrícola e políticas de adaptação às mudanças climáticas no Mato Grosso e na Bretagne [58].

\section{Results and Discussion}

\subsection{Stakeholder's Attitudes Towards Weather and Climate, and Consequences for Agricultural Practices}

In the municipalities of Sinop and Alta Floresta, many of the key stakeholders' views in 2014 remained the same in 2018, particularly regarding perceptions of the weather (or climate change), technology, infrastructure, policies and public actions. However, while in 2014 there was some strong friction in relation to international opinion, in 2018 the discourse appeared more consistent and engaged with sustainable development aims and other concepts upheld by the UN.

With the Brazilian media, and with greater access to information, it is relatively safe to say that the regional scenarios developed by the Centro de Previsão do Tempo e Estudos Climáticos (Weather Forecasting and Climate Studies Centre; CPTEC), part of the Instituto Nacional de Pesquisa Espacial (National Institute for Space Research; INPE), are now familiar to many agricultural associations and large-scale producers. This means that there is clear access to scientific information.

What can be gathered from producers' responses in the interviews is that increased productivity and financial gain are the most common reasons behind the majority of decision-making processes. For example, in the crop-livestock-forestry integration experiment (ILPF [54]; Figure 2a), the selection of tree species to be planted in the program on any given property is based both on productivity gains for the system as a whole and the forestry economic potential. Regarding pests and blight, concerns around production costs are considerable, as all other production costs are basically standardized (seed quantity, fertilizer quantity, etc.). Thus, there seem to be no questions about the production system 
and the new opportunities for both the production and the construction of new markets, for example via agro-ecological production, the establishment of transition protocols, and the construction of interfaces between the agro-ecological and climate change sectors. The producers of Mato Grosso do not make provisions concerning climate change in their agricultural practices $[21,35]$ and consider that the current climate is favorable to productivity levels. At the same time, notable events and a perception of rainfall pattern changes are brought up in many informal conversations: "The rainy season is variable, there is no clear pattern. 2010 and 2012 were dry years, whereas there was too much rain in 2004, 2005 and 2008"; "In January 2004 we lost soy production due to floods; in 2008 there were droughts, and in 2009 the rainy season was displaced: it started later but lasted longer too"; "2014 was like 2004, very rainy. It is always so for years ending in ' 4 "; "Nobody knows anymore when is the rainy season", and "It has become drier, the dry season is longer".

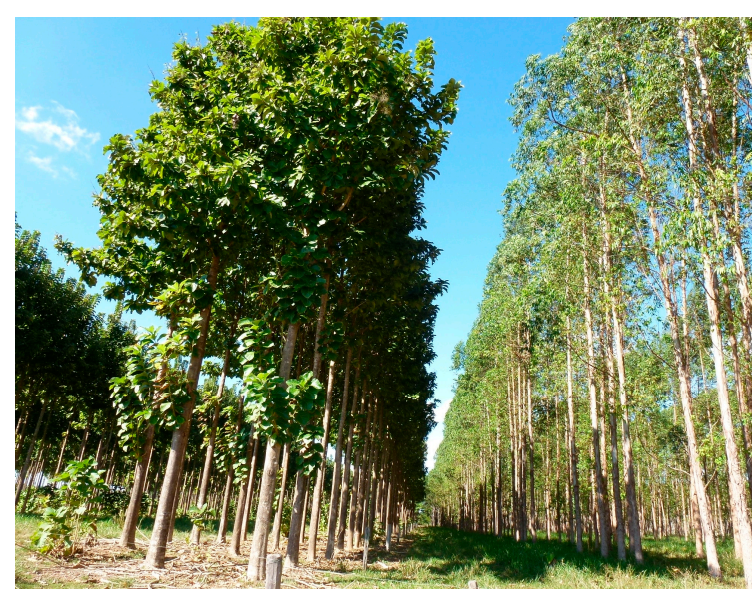

(a)

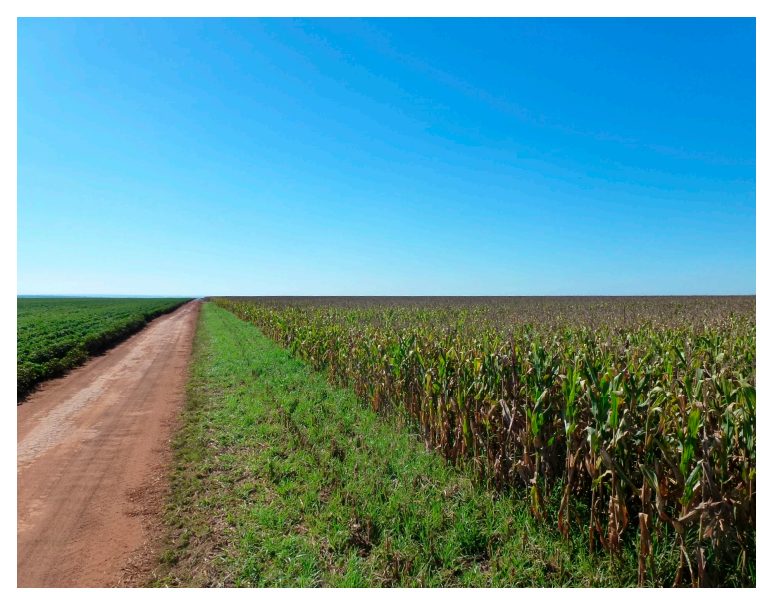

(b)

Figure 2. (a) Teak planting (Tectona grandis; left hand row) and Eucalyptus (right hand row) at Fazenda Gramada, as part of the crop-livestock-forestry integration system (ILPF), in partnership with Embrapa (MT). Eucalyptus planting is considered more profitable than that of teak. (b) Maize and fodder (on the right) and cotton (left) at Fazenda Carigi (MT). Sowing is done straight after soy harvest. [Photo credit: BMF].

The stakeholders interviewed identified climatic phenomena such as the El Niño Southern Oscillation (ENSO), accompanied by data on the percentage of ground water (via several websites such as CPTEC/INPE and established state research foundations). They also follow climate events, and as soon as the "risk window" is over, they start planting soy: (a) for large producers, sowing is done the following day, even if there is a little rain $(10$ to $15 \mathrm{~mm}$ ) as they also sow other crops (maize and/or cotton, Figure 2b); (b) average producers will wait until the beginning of October because with three to six months of dry season they rely more heavily on the moisture content of the soil. Figure 3 illustrates the average duration of the rainy season in Mato Grosso and surrounding regions, based on satellite data [36]. In Mato Grosso, the rainy season lasts from five to just over six months; the soy cycle lasts from three to four months, and this makes the practice of "double cropping" possible [35,63]; the second cropping is called locally as "safrinha". Nevertheless, the high variability of start and end dates of the rainy season (Figure $2 \mathrm{~b}$ ) leads to agricultural production being highly vulnerable to climatic events. In this context, a key stakeholder assesses that "the impact of precipitation patterns variations is stronger when the rainy season ends in April than in May, as the 'safrinha' can be compromised", while another declared that "In recent years the rains have extended for so long that in 2016 the Midwest Development Fund provided incentives for silo constructions to accommodate the surplus production of corn from the 'safrinha'". 


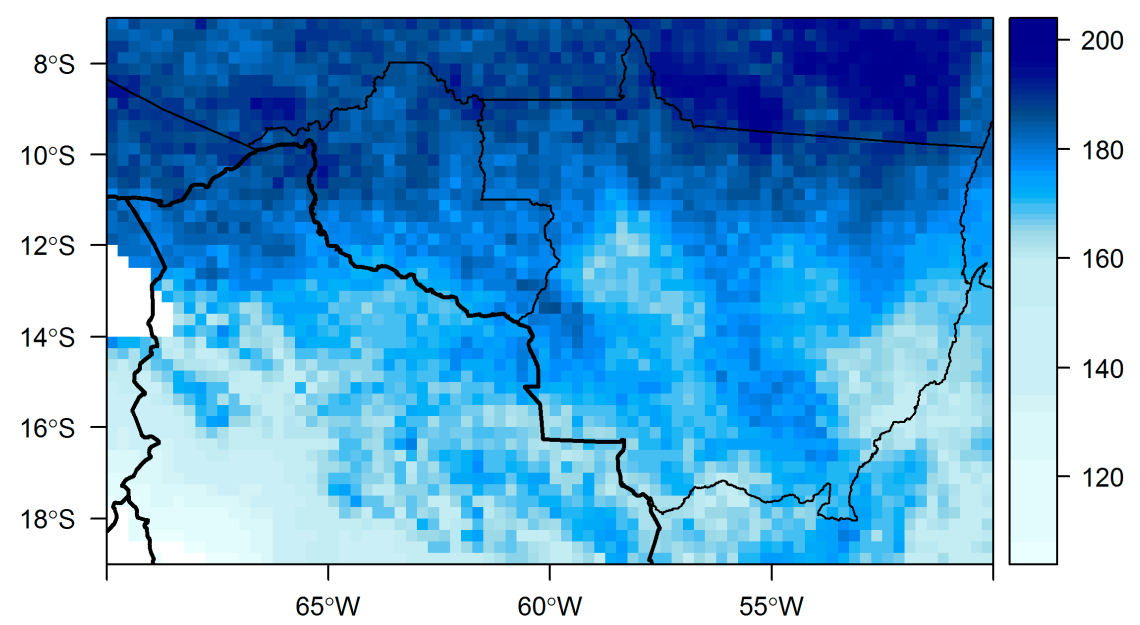

(a)

Trend towards an early end to the rainy season

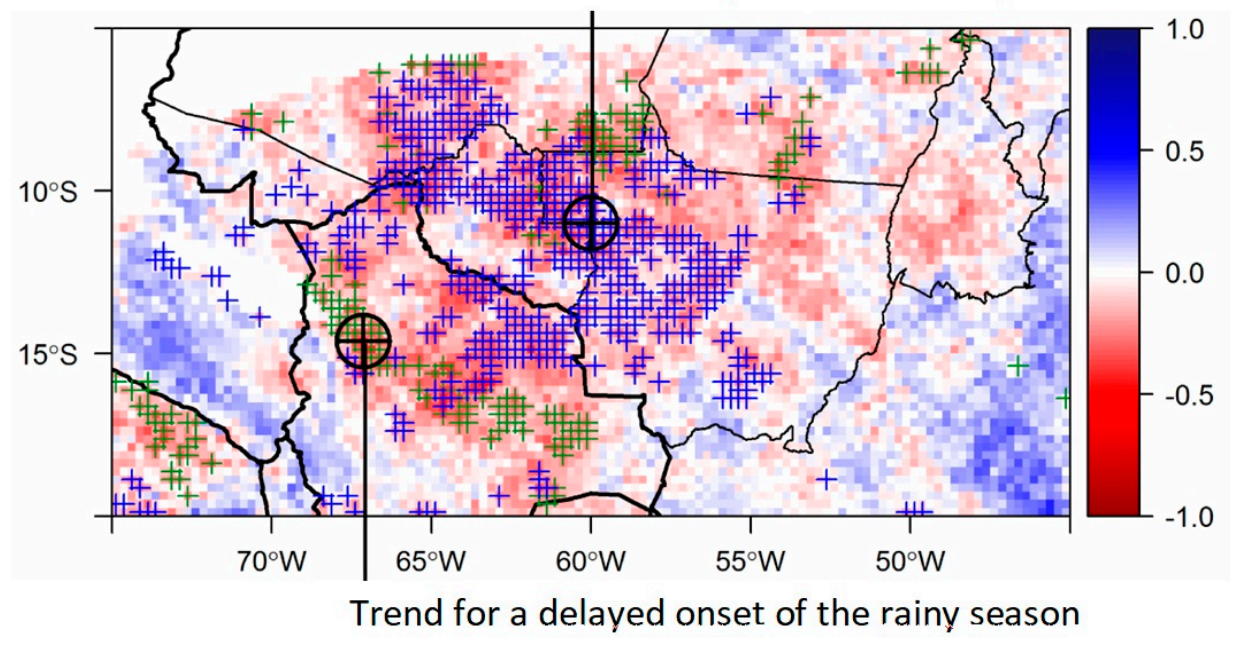

(b)

Figure 3. (a) Average duration of the rainy season (number of days) in Mato Grosso and surrounding regions, based on satellite-based precipitation estimates. (b) Value $\tau$ of the Mann-Kendall trends for the duration of the rainy season. Green crosses (blue) denote statistically significant values of an early onset (end) to the rainy season. Source: Arvor et al. [36].

The technological development of seeds (maize and soy) is seen as a natural solution to difficulties related to reliance on rainfall (and early onset or end to the rainy season). Producers note the length of the rainy season and any reduction to the dry season, which is concentrated over July/August/September. Four seed varieties have been developed. The very early and early varieties accommodate a certain tolerance to a delayed start of the rainy season, as it allows a second cropping (safrinha). This allows producers to opt for long or short cultivation cycles. It should be noted that the biological cycle of crops has changed as harvest can start in January/February and can be completed by mid-March. This is what makes the very early variety so important for producers in light of climate change, and it is an increasing presence amongst the wider number of varieties that are planted. In this sense, climate change can lead to ambiguity on the part of producers as, on one hand, it can provide larger crops, while, on the other hand, it is a consequence of deforestation for crop and pasture expansion.

Associations, foundations and research institutes maintain regular contact with producers. The centres for the Associação dos produtores de soja e milho de Mato Grosso (Mato Grosso Soy and Maize Producers' Association; APROSOJA) and the Fundação Rio Verde (Rio Verde Foundation) 
monitor weather events throughout harvests. Both producers and the Instituto Mato-grossense de Economia Agropecuária (Mato-Grosso Institute of Agricultural Economics; IMEA) produce daily reports. This institute believes that investment in information and technology is essential, claims that the state government strictly observes slash and burn periods, and that the fire lines started by producers contribute in a positive way to the onset of the rains.

One of the few assessments on the influence of the rains in February 2014 for the 2013/2014 harvest is that these actually limited productive potential, and this study was undertaken by APROSOJA and published in the financial section of the newspaper with the largest circulation in Brazil, Folha de São Paulo (Caderno Mercado, B14, 27th of March 2014). The association notes that the yield for soy was only 3.36 tons/hectare, which limited profits despite the fact that the total volume (26.88 million tons) and the volume of harvest had increased. As the majority of producers (around 70\%) sell their production in advance at an average price, profits were also limited (only BR $\$ 2.60$ per bag of $60 \mathrm{~kg}$ more than the cost price as estimated by IMEA).

APROSOJA is very optimistic about agricultural production in the state and claims that producers are being well advised and supported. It gives the impression that there are no conflicts and that the scenario is beneficial for producers. Regarding climate change, the claim is that there have been "no reports of losses due to climate change, with the exception of the heavy rains over the 2013/2014 harvest and later".

The existing options for research and service foundations, producers, associations, trade unions and decision-makers show that adaptation is slow to take place, as these tend to be cynical of scenarios that seem far-off and unlikely. However, contrastingly, they will accept—at least in part-research and technology that offers them alternative agricultural cultivars. This means that their only adaptations appear to be related to increased production, productivity, profits and gains. The idea to adapt their agricultural practices to their physical geographic footprint to encompass climate change appears to be lost on most stakeholders.

For most Mato Grosso's institutions, organizations and producers, the main challenge for public policy is electricity supply and logistics, and includes storage infrastructure at properties and ports-whether organized according to producer collectives, or to the need for skilled labor. This also takes into consideration the fact that new technology is constantly being introduced, market values are increasing and workers are migrating from one farm to another. The BR-163 highway is the only two-lane, tarmacked north-south route in the State. When Blairo Maggi- the son of late Andre Maggi Group founder, and the world's largest private soybean producer - was governor, he built a tarmacked state network that reduced dependence on this route. Regarding energy supply, the construction of five hydroelectric dams along the Teles Pires River has been essential, just as has another two that are currently being approved in the Juruena River. Here again, one can see adaptation by producers to ensure the maintenance and/or increase of profit margins, but that does not take into account adaptation to (or mitigation of) climate change.

In 2018, several key stakeholders did start to use concepts and terms related to climate and its variability more naturally, although some interviews still reflected a certain cynicism through their terminology and the expressions they used that revealed their continued adherence to traditional practices. For example, a revealing local joke consists in claiming that "the two major environmental problems in the Amazon are SEMA and IBAMA", i.e., two administrations dedicated to environmental preservation: the Mato Grosso State Secretary for Environment (SEMA) and the Brazilian Institute for Environment and Renewable Natural Resources (IBAMA).

Mato Grosso producers continue to believe that the climate is conducive to production and were uniform in their responses to questions about seasonality and climate variability, and the vulnerabilities of productive systems related to climate change. For large producers, the amount of rainfall and sun is excellent, highlighting only that, in the last 10 years, the rainy season has lasted longer (with mid-April having the last rainfall and starting again in October). They continue to follow weather forecasts (CPTEC) and the cost of production (IMEA) to decide when to sow. They have not noticed any 
immediate short-term climate or background changes, and they do not mention the IPCC climate change scenarios A1, A2, B1 and B2 of the AR4 [9], or the RPC scenarios of the AR5 [92], which make projections of prolonged dry season in this region. Yet, beyond speechmaking, facts show that irrigation pivots are proliferating to ensure production of the 'safrinha' in dry years marked by an early demise of the rainy season [93], which is actually a major trend observed in climate studies in the area [36].

Producers' ecological awareness is, above all, concentrated around soil and water quality. In contrast, artificial reservoirs created in fluvial networks for fish farming or irrigation have multiplied in the southeast (Figure 4; [37]) and have raised questions about the potential negative effects on soil hydrology, biodiversity and geo-chemistry. Several studies $[44,45,94-96]$ show that a producer's first concern (i.e., above potential environmental damage) is to support their families, and this argument is confirmed and reinforced in an interview with the Sinop Environment Secretary (2018), reiterating that producers' perspectives on climate are filtered by their notion of potential financial losses from any changes. That economic prosperity is a priority over environmental concerns is not exclusive to the region, as discussed, for example, by Rudel et al. [97], who analyzed deforestation paths and drivers for several regions (Central America, Amazon, Asia).

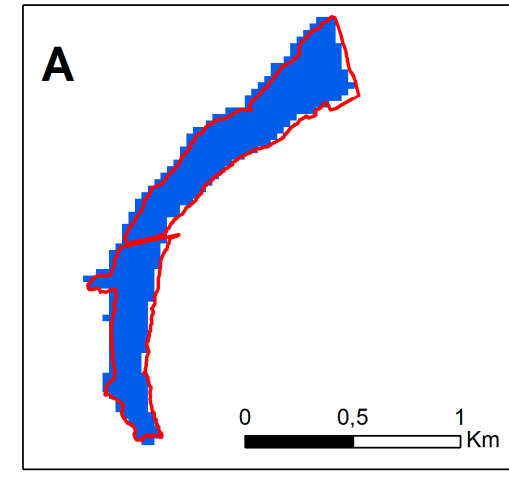

B

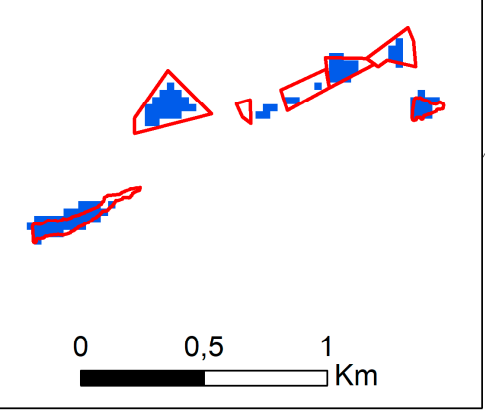

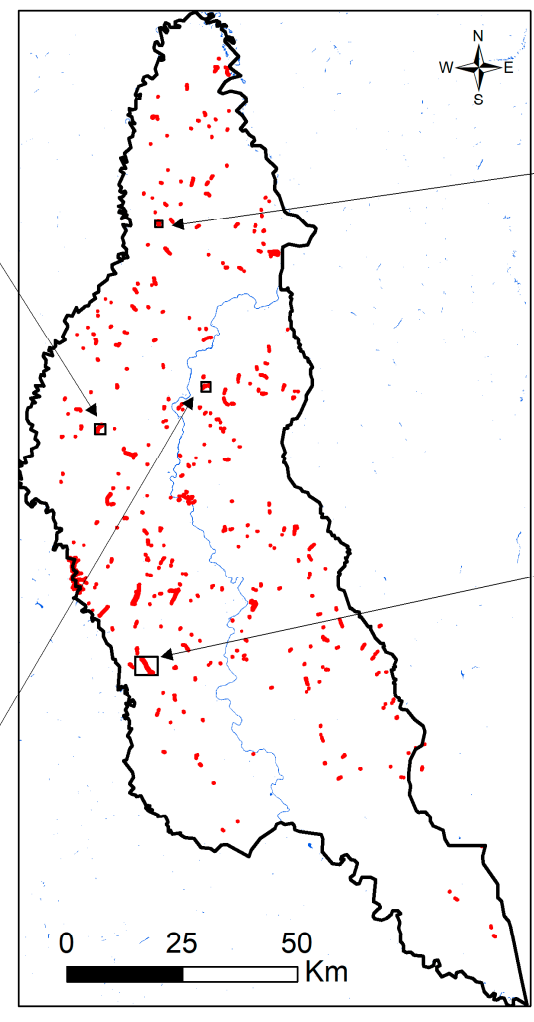
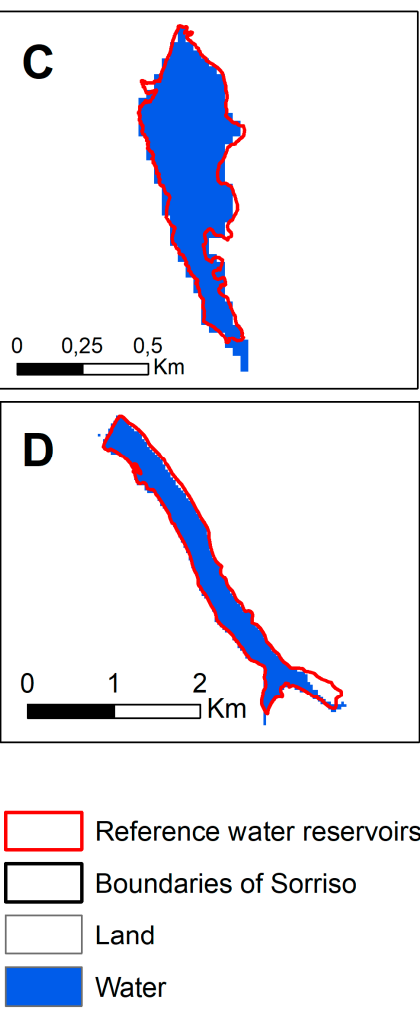

Figure 4. Farm dam that forms artificial reservoirs in the municipality of Sorriso (MT). Source: Arvor et al. [37].

\subsection{Climate Change Perceptions and Municipal Public Actions}

Of importance here is the municipal institutional structure of the (municipal) Departments of Agriculture and of Environment, and the trade unions. The work of federal institutions such as Embrapa, and state institutions like Empaer, stems from certain localized issues. In disseminating ideas and public actions, both federal and state institutions aim to encourage producers to take advantage of all the technical or financial support available. At CoP-21 in Paris (2015), the Mato Grosso state government announced the PCI strategy, "Produce, Conserve and Include", with the aim of raising money by reducing emissions and carbon (approximately $6 \mathrm{Gt} \mathrm{CO}_{2}$ ). This strategy was then joined 
by the "Municípios sustentáveis no MT" ("Mato Grosso Sustainable Cities" of Counties) program, a state-wide initiative to support municipal policy.

The strategy focused on controlling deforestation and developing a low-carbon economy, with the goal of "expanding and increasing efficiency in agricultural and forest production, conserving what is left of the native flora, restoring the natural environment, and enabling socio-economic inclusion within family farming". Both Alta Floresta and Sinop (2018) have producers who are implementing some of the PCI actions within the study area [78], and these are also encouraged to register for "Low-carbon Agriculture" (ABC for Agricultura de Baixo Carbono) projects with the Ministry of Agriculture. For eample, in Alta Floresta, the project Olhos d'Água da Amazônia supported multiple activities to help small rural properties, such as registering with the "Cadastro Ambienal Rural" (CAR; Rural Environmental Registry), encouraging good agricultural practices, and implementing agro-forestry systems, and thereby indirectly helping to reduce environmental damage.

Environmental public policies at the municipal level focus on areas outside agriculture, as "Agriculture falls within the federal and state domains". Among the main concerns of the municipal government in Sinop (in 2018) were the reduction of environmental damage in order to get international certification for their products, verticalization of production and adaptation of crop and animal productions to both national and international markets. Local government action designed to help family farmers provides technical support for funding applications, especially from banks, and also aims to avoid environmental damage and support the verticalization of production so as to meet municipal targets.

Notable amongst several municipal institutions is the Secretaria de Agricultura (Agriculture Department), which does not recognize any long-term variations in the quantity and frequency of rainfall apart from a very few extreme events, declaring that they continue to be able to harvest twice a year. Large producers tend to use precision agriculture for the optimization of production and increased profitability; this can also be interpreted as an effort to minimize the dependency on weather conditions. At the same time, agricultural diversification is encouraged amongst smaller producers through the production of honey, milk, beef cattle and farmed fish. The aim is to install 50 tanks (each tank is a single project), and this requires extra resources relying on a parliamentary amendment and the Programa Nacional de Fortalecimento da Agricultura Familiar (National Program to Strengthen Family Agriculture; Pronaf). The greatest problem in achieving this aim is the lack of professional skills; therefore, access to funding is dependent on following a course at the Serviço Nacional de Aprendizagem Rural (National Rural Learning Service; Senar). The import of $90 \%$ of consumed products is not considered to be a cause for concern by the department.

Their belief is that awareness of environmental issues has begun to impinge on people's consciousness, and people now want to contribute. Younger generations tend to be more aware of these issues, and producers are now beginning to be concerned, particularly about conserving water sources, and are starting to implement reforestation with teak as well as with native trees. However, it seems that of the two conservation strategies, the short-term approach to profit via "adapting" production and even reforestation "type" (with teak) predominates over long-term environmental sustainability. Another action by the department is the production of native flora seedlings for planting in the city, thus meeting aims set by the local council.

However, the Department of the Environment, despite its motto "global-local", considers that the international actions in the context of limiting policies and certification requirements cannot encompass or express the importance of locally developed experiences. While international certifications such as the Mesa Redonda da Soja Sustentável (Round Table on Responsible Soy; RTRS) are relatively easy to acquire, they are very difficult to hold on to. The opinion on climate change and adaptation is that internationally established commitments between countries are not always relevant to local realities. After the presentation of the Lucas do Rio Verde Legal project (a muncipial initiative introduced in 2006 to bring the municpitality's then 670 rural properties up to the standards of the Brazilian Environemental Code $[58,98])$ at CoP21, the consideration was that most major meetings are not 
primarily concerned with local concerns and issues; therefore, it is extremely hard to apply international strategies in municipal scale.

Negotiations may debate correlations between deforestation and climate change, but they are unable to offer funding to local councils and are incapable of understanding why deforestation continues, showing a lack of awareness of grassroots realities. It is still considered vital to disseminate studies among rural producers, especially to those who work with recuperating damaged areas, reducing silting and pesticides, and with water conservation. In spite of their stance on the climate change issue for agriculture, they highlight that the Department's priority is to manage solid waste in the city, and they export rubbish to the Sorriso landfill site. The majority of the local population, which is urban, does not relate to agricultural environmental issues, especially as agricultural licensing is seen as a state responsibility. They mention local business engagement, for example, that of the company Fiagril (Fiagril Participações S.A.) that conducted an oil collection program. However, when the company was bought by the China National Cereals, Oils and Foodstuffs Corporation (COFCO) group, it chose to discontinue it.

Although producers and local policy makers claim that the climate has not changed, the local branch of EMBRAPA claims that producers have increasingly introduced contouring management so as not to lose too much soil due to the absence of previous years' torrential rains, even though 2016 and 2015 saw extremely heavy rainfall (after December there was $1200 \mathrm{~mm}$ of rainfall) and 2014-2015 was very dry. In Sinop, the normal rainfall is about $2100 \mathrm{~mm}$, but the total rainfall in 2018 reached only $1800 \mathrm{~mm}$.

Sinop's Rural Union monitors soy and maize production, and the agricultural producers' association Acrinorte promotes the agri-business technology and marketing fair. They agree with the general perception of the majority of stakeholders: "The climate here is great for agriculture. Some years are better than others, but it's always good for agriculture".

Figure 5 shows a schematic that summarizes the steps in the public action incorporation process following the observation and acknowledgment of climate change, and it highlights inconsistencies in a set of disjunctions. Even though several observational studies point to changes in rainfall patterns within the area studied $[36,39,43,47,48,52]$, the current study has indicated that there are stakeholders who have not noticed any changes in precipitation patterns (for example, a longer dry season). On the other hand, there are also stakeholders who have noticed climatic anomalies through technological means. Of those stakeholders who have perceived climatic anomalies, the logic is generally one of targeting, maintenance and expansion of profits of production and productivity. In this sense, the term "adaptation" is actually a semantic reinterpretation: the theory is linked to the idea of adaptation for the continuation of life; the reality is that, to some extent, adaptation is done in accordance with maintaining and increasing profits, but not necessarily with mitigation of climate change or environmental conservation.

Finally, while public policy managers appear to not negate climate change, in spite of commitments made beyond the scope of the current study it is impossible to say if any developments have been made, or to say that public policies are better able to communicate observations on climate change, even if they encourage the adoption of practices of adaptation and mitigation. In some instances, bitterness regarding focus on deforestation issues and a defensive attitude was bluntly delivered: "Negative effects of urban areas on climate are much more extreme [than deforestation] but nobody talks about this". Ultimately, climate change policies in these territories continue to be slow and gradual, hindered also by the notion that small farmers bear an unfair economical burden [30] when environmental policies are proposed, as stakeholder points: "How to convince a producer to plant around (and not by) the spring, to reforest, to put up a fence... who's gonna bear the cost?" [question posed rethorically]. 


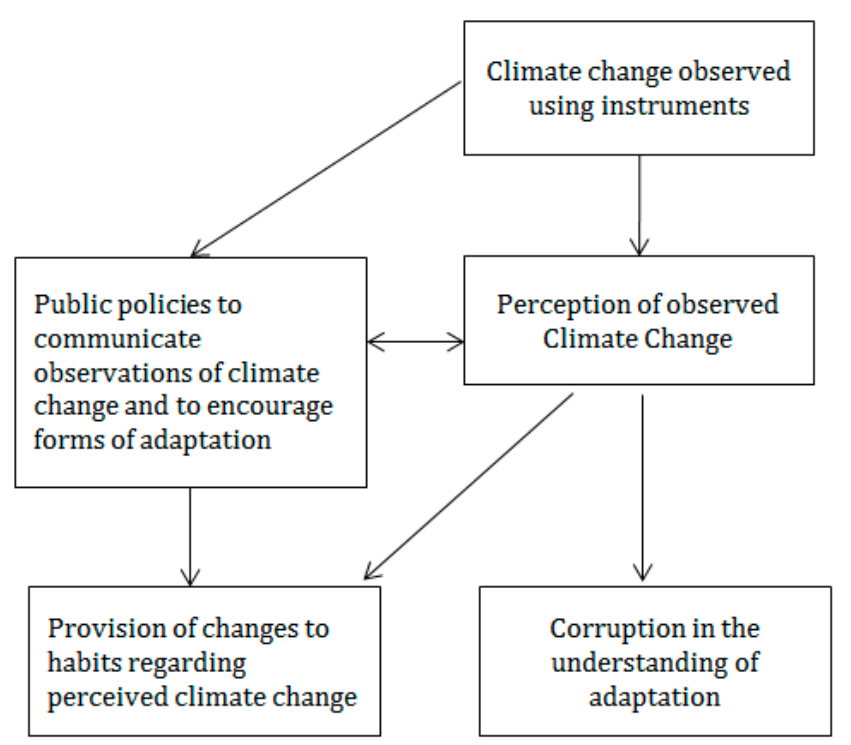

Figure 5. Flowchart of steps in the public action incorporation process of climate change observations.

Since the 2000s, the agricultural sector has evolved rapidly in order to better combine socioeconomic development with environmental governance, and there is a desire of some in the agricultural sector to promote sustainable development. Our results showed that between 2014 and 2018, several of the key stakeholders interviewed began using terms and concepts related to the objectives of sustainable development more confidently, and they began to speak out about suitable transitional public policies that would ensure food security. However, when these issues were more closely scrutinized, several of these stakeholders indicated that they were still not fully convinced by many of the terms and concepts and continued using expressions upholding traditional practices.

In the face of the lack of infrastructure, the lack of support for in-work training and qualifications, and the difficulties in marketing their production, farmers see environmental laws (more generally) and licensing and monitoring parameters as being hindrances and obstacles.

One of the strongest perceptions is related to the belief that agriculture must rely on technology, both machines and seed varieties, which can be adapted to any climate scenario. From the perspective of integrating terms and concepts of adaptation to climate change in public policies, in principle there seems to be no opposition, veto or reluctance on the part of local citizens.

However, municipal public policies and their legal instruments (Municipal Laws, budgets and budget allocation, organizational structures and political powers, collection systems, production, discussion and information dissemination) do not focus on the connection between "agriculture and climate change", and they tend to focus on issues relating to the urban environment. Our findings, based on instrumental case studies, give support to and are aligned with those of Milhorance et al. [59].

Authors such as Weber [12] pointed that appealing to moral and/or social responsibility has the best prospects for sustainable actions for dealing with climate change, though the national political context has an undeniable weight. Nobre et al. [62] proposed a paradigm that could be considered at several levels of governance (federal, state wise or locally) as well as by the private sector in order to improve and/or develop the socio-economic level of the region, while containing deforestation and acting to mitigate its compounding effects to those of global climate change in the Amazon region. Beyond recommendations given by several authors (enforcement of the Forest Code, anti-deforestation plans, regulation of land appropriation and use, voluntary market mechanisms, innovative management of land use; e.g., $[41,50,55,56,60,61,65,66,76,99-101])$, in general, we echo Weber [12], Nobre et al. [62] and Mello-Théry [102], among others, in that education on climate change and closing the gap (perceived or real) between scientists, stakeholders and laypeople are crucial to develop a relationship of trust that will enable a conjoint action of development and climate change 
mitigation. There is a need to appease an ongoing feeling that "discussions on climate change are high up in the sky whereas they [public decision-making on climate change] happen at ground level. Public policies do not come from the base", and that "Public policies are based on taxing people rather than supporting and educating". In this regard, we wish to emphasize the importance of local leaders, and especially producers, to stimulate debate on climate change at local scale in order to further promote bottom-up approaches in the environmental governance model, as it was the case for the Lucas do Rio Verde Legal project, which was first implemented at municipality level before being transferred to state level. Finally, issues that were not treated here and are open to further studies include public policies and consequences for public health, for example, policies that regulate the use of pesticides and their consequences on human or society's health.

Author Contributions: Conceptualization, methodology and original draft preparation: N.A.d.M.-T.; interviews: N.A.d.M.-T. (2014, 2018), V.D. (2014, 2018), B.M.F. (2018), and D.A. (2018); analysis and discussion of results, writing and revisions: N.A.d.M.-T., E.d.L.C., B.M.F., D.A., and V.D. All authors have read and agreed to the published version of the manuscript.

Funding: This work was conducted with funding from the European Union's Horizon 2020 Research and innovation program under the Marie Skłodowska Curie grant ODYSSEA ( $\left.{ }^{\circ} 691053\right)$, and the CNRS IEA SCOLTEL project. Interviews in 2014 were supported by the CNPq Grant CSF (Ciência sem Fronteiras) 201392-2012-7, and by the French ANR DURAMAZ-2 (ANR-11-BSH1-0003) project.

Acknowledgments: The authors thank the several interviewed actors in this study who kindly took the time to receive us and agreed to the publishing of the interviews. We also thank the suggestions of four anonymous reviewers that helped improve the original manuscript.

Conflicts of Interest: The authors declare no conflicts of interest.

\section{References}

1. Cook, J.; Oreskes, N.; Doran, P.T.; Anderegg, W.R.L.; Verheggen, B.; Maibach, E.W.; Carlton, J.S.; Lewandowsky, S.; Skuce, A.G.; Green, S.A.; et al. Consensus on consensus: A synthesis of consensus estimates on human-caused global warming. Environ. Res. Lett. 2016, 11. [CrossRef]

2. Leiserowitz, A.A.; Maibach, E.W.; Roser-Renouf, C.; Smith, N.; Dawson, E. Climategate, public opinion, and the loss of trust. Am. Behav. Sci. 2013, 57, 818-837. [CrossRef]

3. Lewandowsky, S.; Oreskes, N.; James, S.; Risbey, B.; Newell, R.; Smithson, M. Climate change denial and its effect on the scientific community. Glob. Environ. Chang. 2015, 33, 1-13. [CrossRef]

4. Kim, S.Y.; Wolinsky-Nahmias, Y. Cross-national public opinion on climate change: The effects of affluence and vulnerability. Glob. Environ. Politics 2014, 14, 79-106. [CrossRef]

5. Palier, B.; Surel, Y. Les «Trois I» et l'analyse de l'état en action, Presses de Sciences Po. Rev. Française Sci. Polit. 2005, 55, 7-32. [CrossRef]

6. Fawcett, A.A.; Iyer, G.C.; Clarke, L.E.; Edmonds, J.A.; Hultman, N.E.; McJeon, H.C.; Rogelj, J.; Schuler, R.; Alsalam, J.; Asrar, G.R.; et al. Can Paris pledges avert severe climate change? Science 2015, 350, 1168-1169. [CrossRef]

7. Spash, C.L. This changes nothing: The Paris agreement to ignore reality. Globalizations 2016, 13, 928-933. [CrossRef]

8. Kinley, R. Climate change after Paris: From turning point to transformation. Clim. Policy 2017, 17, 9-15. [CrossRef]

9. IPCC. Summary for Policymakers. In Climate Change: Impacts, Adaptation and Vulnerability. Contribution of Working Group II to the Fourth Assessment Report of the Intergovernmental Panel on Climate Change; Parry, M.L., Canziani, O.F., Palutikof, J.P., van der Linden, P.J., Hanson, C.E., Eds.; Cambridge University Press: Cambridge, UK, 2007; pp. 7-22.

10. Biermann, F.; Gupta, A. Accountability and legitimacy in earth system governance. Ecol. Econ. 2011, 70, 1856-1864. [CrossRef]

11. Carpenter, C. Businesses, Green Groups and The Media: The Role of Non-Governmental Organizations in the Climate Change Debate. Int. Aff. 2001, 77, 313-328. [CrossRef]

12. Weber, E.U. What shapes perceptions of climate change? WIREs Clim. Chang. 2010, 1, 332-342. [CrossRef] 
13. O'Connor, R.E.; Bard, R.J.; Fisher, A. Risk Perceptions, General Environmental Beliefs, and Willingness to Address Climate Change. Risk Anal. 1999, 19, 461-471. [CrossRef]

14. Leiserowitz, A. Climate Change Risk Perception and Policy Preferences: The Role of Affect, Imagery, and Values. Clim. Chang. 2006, 77, 45-72. [CrossRef]

15. Weber, E.U. What shapes perceptions of climate change? New research since 2010. WIREs Clim. Chang. 2016, 7, 125-134. [CrossRef]

16. Mendonça, F. La connaissance du climat au Brésil: Entre le vernaculaire et le scientifique. Confins 2012, 15. [CrossRef]

17. Sterman, J.D. Risk communication on climate: Mental models and mass balance. Science 2008, 322, 532-533. [CrossRef]

18. Spence, A.; Poortinga, W.; Butler, C.; Pidgeon, N.F. Perceptions of climate change and willingness to save energy related to flood experience. Nat. Clim. Chang. 2011, 1, 46-49. [CrossRef]

19. Hansen, J.; Sato, M.; Ruedy, R. Perception of climate change. PNAS 2012, 109, E2415-E2423. [CrossRef]

20. Rudiak-Gould, P. The influence of Science communication on indigenous climate change perception: Theoretical and practical implications. Hum. Eco. 2014, 42, 75-86. [CrossRef]

21. Funatsu, B.M.; Dubreuil, V.; Racapé, A.; Debortoli, S.N.; Nasuti, S.; Le Tourneau, F.-M. Perceptions of climate and climate change by Amazonian communities. Glob. Environ. Chang. 2019, 57, 101923. [CrossRef]

22. Füsser, H.-M. Adaptation planning for climate change: Concepts, assessment approaches, and key lessons. Sustain. Sci. 2007, 2, 265-275. [CrossRef]

23. Preston, B.L.; Dow, K.; Berkhout, F. The Climate Adaptation Frontier. Sustainability 2013, 5, 1011-1035. [CrossRef]

24. Warner, K.; Zommers, Z.; Wreford, A.; Hurlbert, M.; Viner, D.; Scantlan, J.; Halsey, K.; Halsey, K.; Tamang, C. Characteristics of Transformational Adaptation in Climate-Land-Society Interactions. Sustainability 2019, 11, 356. [CrossRef]

25. Agrawal, A.; Carmen Lemos, M. Adaptive development. Nature Clim. Chang. 2015, 5, 185-187. [CrossRef]

26. Milhorance, C.; Sabourin, E.; Le Coq, J.-F.; Mendes, P. Unpacking the policy mi of adaptation to climate change in Brazil's semiarid region: Enabling instruments and coordination mechanisms. Clim. Policy 2020, 20, 593-608. [CrossRef]

27. Coles, A.R.; Scott, C.A. Vulnerability and adaptation to climate change and variability in semi-arid rural southeastern Arizona, USA. Nat. Resour. Forum 2009, 33, 297-309. [CrossRef]

28. Goldstein, A.; Turner, W.R.; Gladstone, J.; Hole, D.G. The private sector's climate change risk and adaptation blind spots. Nat. Clim. Chang. 2019, 9, 18-25. [CrossRef]

29. Nasuti, S.; Curi, M.V.; da Silva, N.M.; de Andrade, A.J.P.; Ibiapina, I.; de Souza, C.R.; Saito, C.H. Conhecimento tradicional e previsões meteorológicas: Agricultores familiares e as experiências de inverno no Semiárido Potiguar. Rev. Econ. NE. 2013, 44, 383-402. (in Portuguese).

30. Macedo, M.N.; DeFries, R.S.; Morton, D.C.; Stickler, C.M.; Galford, G.L.; Shimabukuro, Y.E. Decoupling of deforestation and soy production in the southern Amazon during the late 2000s. PNAS 2012, 109, 1341-1346. [CrossRef]

31. Arvor, D.; Daugeard, M.; Tritsch, I.; Mello-Théry, N.A.; Théry, H.; Dubreuil, V. Combining socioeconomic development with environmental governance in the Brazilian Amazon: The Mato Grosso agricultural frontier at a tipping point. Environ. Dev. Sustain. 2018, 20, 1-22. [CrossRef]

32. Arima, E.Y.; Barreto, P.; Araújo, E.; Soares-Filho, B. Public policies can reduce tropical deforestation: Lessons and challenges from Brazil. Land Use Policy 2014, 41, 465-473. [CrossRef]

33. Arvor, D.; Dubreuil, V.; del Villar, P.M.; Ferreira, C.M.; Meirelles, M.S.P. Développement, crises et adaptation des territories du soja au Mato Grosso: L'exemple de Sorriso. Confins 2009, 6. (In French)

34. Arvor, D.; Meirelles, M.; Dubreuil, V.; Bégué, A.; Shimabukuro, Y.E. Analyzing the agricultural transition in Mato Grosso, Brazil, using satellite-derived indices. Appl. Geogr. 2012, 32, 702-713. [CrossRef]

35. Arvor, D.; Dubreuil, V.; Ronchail, J.; Simões, M.; Funatsu, B.M. Spatial patterns of rainfall regimes related to levels of double cropping agriculture systems in Mato Grosso (Brazil). Int. J. Climatol. 2014, 34, 2622-2633. [CrossRef]

36. Arvor, D.; Funatsu, B.M.; Michot, V.; Dubreuil, V. Monitoring rainfall patterns in the Southern Amazon with PERSIANN-CDR data: Long-term characteristics and trends. Remote Sens. 2017, 9, 889. [CrossRef] 
37. Arvor, D.; Daher, F.R.F.; Briand, D.; Dufour, S.; Rollet, A.-J.; Simões, M.; Ferraz, R.P.D. Monitoring thirty years of small water reservoirs proliferation in the southern Brazilian Amazon with Landsat time series. ISPRS J. Photogramm. Remote Sens. 2018, 145. [CrossRef]

38. Bariou, R.; Dos Passos, M.M.; Clairay, M. Aspects de la colonization agricole dans le Mato Grosso. Photo Interprétation 1996, 34, 105-111.

39. Chambers, J.Q.; Artaxo, P. Deforestation size influences rainfall. Nat. Clim. Chang. 2017, 7, $175-176$. [CrossRef]

40. Clairay, M.; Dubreuil, V. Etude de l'évolution diachronique de la Gleba Celeste (Mato Grosso) à partir d'images Landsat. Espaço Geogr. 2002, 5, 119-138.

41. Costa, M.H.; Fleck, L.C.; Cohn, A.S.; Abrahão, G.M.; Brando, P.M.; Coe, M.T.; Fu, R.; Lawrance, D.; Pires, G.F.; Pousa, R.; et al. Climate risks to Amazon agriculture suggest a rationale to conserve local ecosystems. Front. Ecol. Environ. 2019, 17, 584-590. [CrossRef]

42. Coy, M.; Klingler, M.; Kohlhepp, G. De frontier até pós-frontier: Regiões pioneiras no Brasil dentro do processo de transformação espaço-temporal e sócio-ecológico. Confins 2017, 30. [CrossRef]

43. Debortoli, N.S.; Dubreuil, V.; Funatsu, B.; Delahaye, F.; de Oliveira, C.; Rodrigues-Filho, S.; Saito, C.H.; Fetter, R. Rainfall patterns in the Southern Amazon: A chronological perspective (1971-2010). Clim. Chang. 2015, 132, 1-20. [CrossRef]

44. Diegues, A.C.S.A.; Kageyama, P.; Viana, V. The Social Dynamics of Deforestation in the Brazilian Amazon: An Overview; UNRISD Discussion Paper, no. 36; United Nations Research Institute for Social Development: Genebra, Switzerland, 1992. Available online: http://www.unrisd.org/80256B3C005BCCF9/(httpPublications) /4DF569C03BC4FE5480256B640055E523?OpenDocument\&panel=relatedinformation (accessed on 7 June 2020).

45. Droulers, M.; Le Tourneau, F.M. (Eds.) L'Amazonie Brésilienne et le Développement Durable; Éditions Belin: Paris, France, 2010; p. 477.

46. Dubreuil, V.; Laques, A.; Nédélec, V.; Arvor, D.; Gurgel, H. Paysages et fronts pionniers amazoniens sous le regard des satellites: L'exemple du Mato Grosso. L'Espace Géographique 2008, 37, 57-74. [CrossRef]

47. Dubreuil, V.; Debortoli, N.; Funatsu, B.M.; Nedelec, V.; Durieux, L. Impact of land-cover change in the Southern Amazonia Climate: A case study for the region of Alta Floresta, Mato Grosso, Brazil. Environ. Monit. Assess. 2012, 184, 877-891. [CrossRef] [PubMed]

48. Dubreuil, V.; Funatsu, B.M.; Michot, V.; Nasuti, S.; Debortoli, N.; De Mello-Thery, N.A.; Le Tourneau, F.M. Local rainfall trends and their perceptions by Amazonian communities. Clim. Chang. 2017, 143, 461-472. [CrossRef]

49. Fearnside, P.M. Soybean cultivation as a threat to the environment in Brazil. Environ. Conserv. 2001, 28, $23-38$. [CrossRef]

50. Fearnside, P.M. Deforestation control in Mato Grosso: A new model for slowing the loss of Brazil's Amazon forest. Ambio 2003, 32, 343-345. [CrossRef]

51. Fearnside, P.M.; Barbosa, R.I. Avoided deforestation in Amazonia as a global warming mitigation measure: The case of Mato Grosso. World Resour. Rev. 2003, 15, 352-361.

52. Fu, R.; Yin, L.; Li, W.; Arias, P.A.; Dickinson, R.E.; Huang, L.; Chakraborty, S.; Fernandes, K.; Liebmann, B.; Fisher, R.; et al. Increased dry-season length over southern Amazonia in recent decades and its implication for future climate projection. PNAS 2013, 110, 18110-18115. [CrossRef]

53. Funatsu, B.M.; Dubreuil, V.; Claud, C.; Arvor, D.; Gan, M.A. Convective activity in Mato Grosso state (Brazil) from microwave satellite observations: Comparisons between AMSU and TRMM datasets. J. Geophys. Res. 2012, 117, D16109. [CrossRef]

54. Gil, J.; Siebold, M.; Berger, T. Adoption and development of integrated crop-livestock-forestry systems in Mato Grosso, Brazil, Agriculture. Ecosyst. Environ. 2015, 199, 394-406. [CrossRef]

55. Kastens, J.H.; Brown, J.C.; Coutinho, A.C.; Bishop, C.R.; Esquerdo, J.C.D.M. Soy moratorium impacts on soybean and deforestation dynamics in Mato Grosso, Brazil. PLoS ONE 2017, 12, e0176168. [CrossRef] [PubMed]

56. Lapola, D.M.; Martinelli, L.A.; Peres, C.A.; Ometto, J.P.H.B.; Ferreira, M.E.; Nobre, C.A.; Aguiar, A.P.D.; Bustamante, M.M.C.; Cardoso, M.F.; Costa, M.F.; et al. Pervasive transition of the Brazilian land-use system. Nat. Clim. Chang. 2013, 4, 27-35. [CrossRef] 
57. Le Tourneau, F.M.; Nasuti, S.; Marchand, G.; Greissing, A.; Bursztyn, M.; Léna, P.; Dubreuil, V. DURAMAZ indicator system: A cross-disciplinary comparative tool for assessing ecological and social changes in the Amazon. Philos. Trans. R. Soc. Biol. Sci. 2013, 368, 1-10. [CrossRef] [PubMed]

58. Mello-Théry, N.A. Scientific report on the Agricultural Production Sustainability Project and on adaptation policies to climate change in Mato Grosso and Brittany. CNPq Grant CSF 201392-2012-7, 2014 (unpublished).

59. Milhorance, C.; Bursztyn, M.; Sabourin, E. From policy mix to policy networks: Assessing climate and land use policy interactions in Mato Grosso, Brazil. J. Environ. Policy Plan. 2020, 22, 381-396. [CrossRef]

60. Nepstad, D.; McGrath, D.; Stickler, C.; Alencar, A.; Azevedo, A.; Swette, B.; Bezerra, T.; DiGiano, M.; Shimada, J.; Motta, R.S.; et al. Slowing Amazon deforestation through public policy and interventions in beef and soy supply chains. Science 2014, 344, 1118-1123. [CrossRef]

61. Nepstad, D.; Soares-Filho, B.S.; Merry, F.; Lima, A.; Moutinho, P.; Carter, J.; Bowman, M.; Cattaneo, A.; Rodrigues, H.; Schwartzman, S.; et al. The End of Deforestation in the Brazilian Amazon. Science 2009, 326, 1350-1351. [CrossRef]

62. Nobre, C.A.; Sampaio, G.; Borma, L.S.; Castilla-Rubio, J.C.; Silva, J.S.; Cardoso, M. Land-use and climate change risks in the amazon and the need of a novel sustainable development paradigm. PNAS 2016, 113, 759-768. [CrossRef]

63. Spera, S.A.; Cohn, A.S.; VanWey, L.K.; Mustard, J.F.; Rudorff, B.F.; Risso, J.; Adami, M. Recent cropping frequency, expansion, and abandonment in Mato Grosso, Brazil had selective land characteristics. Environ. Res. Lett. 2014, 9, 064010. [CrossRef]

64. Soler, L.S.; Vergurg, P.H.; Alves, D.S. Evolution of land use in the Brazilian Amazon: From frontier expansion to market chain dynamics. Land 2014, 3, 981-1014. [CrossRef]

65. Stickler, C.M.; Nepstad, D.C.; Azevedo, A.A.; McGrath, D.G. Defending public interests in private lands: Compliance, costs and potential environmental consequences of the Brazilian Forest Code in Mato Grosso. Phil. Trans. R. Soc. Biol. Sci. 2013, 368, 20120160. [CrossRef] [PubMed]

66. Tritsch, I.; Arvor, D. Transition in environmental governance in the Brazilian Amazon: Emergence of a new pattern of socio-economic development and deforestation. Land Use Policy 2016, 59, 446-455. [CrossRef]

67. Richards, P.; Pellegrina, H.; VanWey, L.; Spera, S. Soybean development: The impact of a decade of agricultural change on urban and economic growth in Mato Grosso, Brazil. PLoS ONE 2015, 10, e0122510. [CrossRef] [PubMed]

68. Rocha, B.; Grisa, C.; Niederle, P. Quand le "public" et le "Privé" se Rencontrent dans la Frontière: Analyse d'une Experience de Developpement dans l'Amazonie Brésilienne; ISDA: Montpellier, France, 2010; p. 10.

69. VanWey, L.K.; Spera, S.; de Sa, R.; Mahr, D.; Mustard, J.F. Socioeconomic development and agricultural intensification in Mato Grosso. Phil. Trans. R. Soc. Biol. Sci. 2013, 368, 20120168. [CrossRef] [PubMed]

70. Zu Ermgassen, E.K.; Alcântara, M.P.; Balmford, A.; Barioni, L.; Neto, F.B.; Bettarello, M.M.F.; Brito, G.D.; Carrero, G.C.; Florence, E.D.A.; Garcia, E.; et al. Results from On-The-Ground Efforts to Promote Sustainable Cattle Ranching in the Brazilian Amazon. Sustainability 2018, 10, 1301. [CrossRef]

71. Mello-Théry, N.A. L'Amazonie entre les myriades d'expériences et les politiques publiques dominantes. Confins 2016, 26. [CrossRef]

72. Mello-Théry, N.A. Politiques environnementales brésiliennes: Intentions et réalités. EchoGéo $2017,41$. [CrossRef]

73. Mello-Théry, N.A. Perspectivas ambientais 2019: Retrocessos na política governamental. Confins $2019,501$. [CrossRef]

74. MelloThéry, N.A.; Van Tilbeurgh, V. Da teologia da libertação ao desenvolvimento sustentável na Amazônia brasileira: Os mecanismos políticos e sociais de sua interpretação. Revista NERA (UNESP) 2011, 19, 59-72.

75. Caldas, E.L.; Moreira, I. Políticas de desenvolvimento territorial e intermunicipalidade no Brasil: Complementaridades e tensões. Sustain. Debate 2013, 4. [CrossRef]

76. Gibbs, H.K.; Rausch, L.; Munger, J.; Schelly, I.; Morton, D.C.; Noojipady, P.; Soares-Filho, B.; Barreto, P.; Micol, L.; Walker, N.F. Brazil's soy moratorium. Science 2015, 347, 377-378. [CrossRef] [PubMed]

77. Schouten, G.; Leroy, P.; Glasbergen, P. On the deliberative capacity of private multi-stakeholder governance: The Roundtables on Responsible Soy and Sustainable Palm Oil. Ecol. Econ. 2012, 83, 42-50. [CrossRef]

78. De Paulo, C. As Políticas de Biodiversidade e de Mudanças Climáticas: (des)Articulações e Reflexos Sobre o Mosaico de Conservação do Cristalino/MT. Ph.D. Thesis, Programa de pós graduação em Ciencia Ambiental-Procam, Universidade de São Paulo, São Paulo, Brazil, 2016. (In Portuguese) 
79. Shreraga, J.D.; Elbi, K.L.; Furlow, J.; Moreno, A.R. From science to policy: Developing responses to climate change. In Climate Change and Human Health: Risks and Responses; McMichael, A.J., Campbell-Lendrum, D.H., Corvalan, C.F., Ebi, K.L., Githeko, A., Scheraga, J.D., et al., Eds.; World Health Organization (WHO), World Meteorological Organization (WMO), United Nations Environment Programme (UNDP), World Health Organization: Geneva, Switzerland, 2003; pp. 237-266.

80. Carneiro, M.J.; da Silva Rosa, T. The use of scientific knowledge in the decision making process of environmental public policies in Brazil. J. Sci. Commun. 2011, 10, A03. [CrossRef]

81. Pérard, J. Risques climatiques et espace vécu dans le domaine intertropical. In Le Climat, l'Eau et les Hommes-Ouvrage en l'Honneur de Jean Mounier; Dubreuil, V., Ed.; Presses Universitaires de Rennes: Rennes, France, 1997; pp. 105-111.

82. Godard, O. L'organisation internationale de la lutte contre l'effet de serre. Une revue critique des thèses du rapport de Jean Tirole. L'Économie Polit. 2010, 2, 82-106. (in French).

83. Van Tilbeurgh, V.; Vertes, F.; Roche, B.; Thenail, C. Les exploitations laitières développent-elles une flexibilité face aux évolutions climatique? In Changement Climatique dans l'Oues; Merot, P., Dubreuil, V., Delahaye, D., Desnos, P., Eds.; Presses Universitaires de Rennes: Rennes, France, 2012; pp. 121-151.

84. Obermaier, M.; Pinugelli Rosa, L. Mudança climática e adaptação no Brasil: Uma análise crítica. Estudos Avançados 2013, 27, 155-176. (in Portuguese). [CrossRef]

85. Sampaio, G.; Nobre, C.; Costa, M.H.; Satyamurty, P.; Soares-Filho, B.S.; Cardoso, M. Regional climate change over eastern Amazonia caused by pasture and soybean cropland expansion. Geophys. Res. Lett. 2007, 34, L17709. [CrossRef]

86. Lawrence, D.; Vandecar, K. Effects of tropical deforestation on climate and agriculture. Nat. Clim. Chang. 2015, 5, 27-36. [CrossRef]

87. Staal, A.; Flores, B.M.; Aguiar, A.P.D.; Bosmans, J.H.C.; Fetzer, I.; Tuinenburg, O.A. Feedback between drought and deforestation in the Amazon. Environ. Res. Lett. 2020, 15, 044024. [CrossRef]

88. Drews, S.; Van Den Bergh, J.C.J.M. What explains public support for climate policies? A review of empirical and experimental studies. Clim. Policies 2016, 16, 855-876. [CrossRef]

89. Anderegg, W.R.L.; Goldsmith, G.R. Public interest in climate change over the past decade and the effects of the "climategate" media event. Environ. Res. Lett. 2014, 9, 111004. [CrossRef]

90. Farjam, M.; Nikolaychuk, O.; Bravo, G. Does risk communication really decrease cooperation in climate change mitigation? Clim. Chang. 2018, 149, 147-158. [CrossRef]

91. Noble, I.R.; Huq, S.; Anokhin, Y.A.; Carmin, J.; Goudou, D.; Lansigan, F.P.; Osman-Elasha, B.; Villamizar, A. Adaptation needs and options. In Climate Change 2014: Impacts, Adaptation, and Vulnerability. Part A: Global and Sectoral Aspects. Contribution of Working Group II to the Fifth Assessment Report of the Intergovernmental Panel on Climate Change; Field, C.B., Barros, V.R., Dokken, D.J., Mach, K.J., Mastrandrea, M.D., Bilir, T.E., Chatterjee, M., Ebi, K.L., Estrada, Y.O., Genova, R.C., et al., Eds.; Cambridge University Press: Cambridge, UK; New York, NY, USA, 2014; pp. 833-868.

92. IPCC. Climate Change 2014: Synthesis Report. Contribution of Working Groups I, II and III to the Fifth Assessment Report of the Intergovernmental Panel on Climate Change; Core Writing Team, Pachauri, R.K., Meyer, L.A., Eds.; IPCC: Geneva, Switzerland, 2014; p. 151.

93. Zaiatz, A.P.S.R.; Zolin, C.A.; Lopes, T.R.; Vendrusculo, L.G. Classificação de áreas irrigadas por pivôs centrais durante o ano de 2014 em uma sub-bacia do alto rio Teles Pires. In Proceedings of the Jornada Científica da Embrapa Agrossilvipastoril, Sinop, Brazil, 1-3 August 2016; pp. 44-47.

94. Martinelli, L.A.; Naylor, R.; Vitousek, P.M.; Moutinho, P. Agriculture in Brazil: Impacts, costs, and opportunities for a sustainable future, Current Opinion. Environ. Sustain. 2010, 2, 431-438.

95. Hayes, N.; Rajão, R. Competing institutional logics and sustainable development: The case of geographic information systems in Brazil's Amazon region. Inf. Technol. Dev. 2011, 17, 4-23. [CrossRef]

96. Pacheco, P.; Poccard-Chapuis, R. The complex evolution of cattle ranching development amid market integration and policy shifts in the Brazilian Amazon. Ann. Am. Assoc. Geogr. 2012, 102, 1366-1390. [CrossRef]

97. Rudel, T.K.; Defries, R.; Asner, G.P.; Laurance, W.F. Changing drivers of deforestation and new opportunities for conservation. Conserv. Biol. 2009, 23, 1396-1405. [CrossRef]

98. Barbosa, L.C. Guardians of the Brazilian Amazon Rainforest: Environmental Organizations and Development; Routledge: London, UK; New York, NY, USA, 2015; p. 248. ISBN 1317577639. 
99. Cohn, A.S.; Mosnier, A.; Havlík, P.; Valin, H.; Herrero, M.; Schmid, E.; O’Hare, M.; Obersteiner, M. Cattle ranching intensification in Brazil can reduce global greenhouse emissions by sparing land from deforestation. PNAS 2014, 111, 7236-7241. [CrossRef]

100. Garcia, E.; Ramos Filho, F.S.V.; Mallmann, G.M.; Fonseca, F. Costs, Benefits and Challenges of Sustainable Livestock Intensification in a Major Deforestation Frontier in the Brazilian Amazon. Sustainability 2017, 9, 158. [CrossRef]

101. Stabile, C.C.; Guimarães, A.L.; Silva, D.S.; Ribeiro, V.; Macedo, M.N.; Coe, M.T.; Pinto, E.; Moutinho, P.; Alencar, A. Solving Brazil's land use puzzle: Increasing production and slowing Amazon deforestation. Land Use Policy 2020, 91, 104362. [CrossRef]

102. Mello-Théry, N.A. O campo é um laboratório para a gestão ambiental. Confins 2020, 45. [CrossRef]

(C) 2020 by the authors. Licensee MDPI, Basel, Switzerland. This article is an open access article distributed under the terms and conditions of the Creative Commons Attribution (CC BY) license (http://creativecommons.org/licenses/by/4.0/). 